\title{
Language disorders and brain lesion topography in aphasics after stroke
}

\author{
Distúrbios de linguagem e topografia da lesão cerebral em afásicos \\ após acidente vascular cerebral
}

Michele Devido-Santos' ${ }^{1}$ Rubens José Gagliardi², Ana Paula Machado Goyano Mac-Kay³

\begin{abstract}
Aphasia is a language disorder associated with focal brain lesions. Although the topographic definition of the language area has been widely accepted, there is not necessarily any direct correlation between the lesion site and the manifested symptoms. Objective: To analyze aspects of language in aphasics in relation to lesion topography. Methods: A prospective, descriptive study of qualitative nature was conducted on 31 individuals, aged older than 15 years, with at least three years of schooling, and a confirmed diagnosis of stroke. Language assessment was carried out using the Montreal Toulouse battery (alpha version), Boston naming test, and FAS test. Language test results were compared against lesion topography findings from magnetic resonance imaging. Results: Heterogeneous results were found when comparing topography with aphasia, non-aphasia, and performance on language scales. Conclusion: No direct relationship was evident between lesion topography, aphasia, and language test performance.
\end{abstract}

Key words: language, aphasia, stroke.

\section{RESUMO}

Afasia é um distúrbio de linguagem associado à lesão cerebral focal. Embora a área de linguagem tenha uma definição topográfica largamente aceita, não se encontra necessariamente uma correlação direta entre o local da lesão e os sintomas manifestados. Objetivo: Analisar aspectos da linguagem em afásicos e a relação com a topografia da lesão. Métodos: Estudo prospectivo, descritivo e de caráter qualitativo e quantitativo, envolvendo 31 indivíduos com idade acima de 15 anos, escolaridade de três anos ou mais e diagnóstico confirmado de acidente vascular cerebral. Foram empregados para avaliação de linguagem o Protocolo Montreal Toulouse (versão alfa), o Teste de Nomeação do Boston e o Teste FAS. Os dados foram comparados com a topografia da lesão, obtidos por ressonância magnética. Resultados: Foi observada heterogeneidade, quando a topografia foi comparada com afasia, não-afasia e o desempenho nas provas de linguagem. Conclusão: Não observou-se relação direta entre a topografia da lesão, a afasia e o desempenho nas provas de linguagem.

Palavras-Chave: linguagem, afasia, acidente vascular cerebral.

According to the diagnostic criteria of the DSM-IV, in 1994 (315.31: Mixed Receptive-Expressive Language Disorder, item b), receptive and expressive communication disorders comprise the group of receptive and expressive language difficulties that interfere in academic and occupational tasks and affect social life ${ }^{1}$.

Aphasia is a language disorder that affects language characteristics to varying degrees. It does not constitute a disease, but, rather, it is a symptom of a neurophysiologic disorder secondary to focal brain lesion ${ }^{2,3}$. Aphasia is a common severe sequela of stroke ${ }^{4}$.
Classically, several areas have been identified as being responsible for language, including Broca's, Wernicke's, and adjacent areas. However, brain-damaged patients with lesions at other sites often manifest symptoms of aphasia, thus indicating a need for further investigations on this topographic relationship. Some authors have reiterated this point, stating that language disorders do not always display a direct correlation with the injury and its symptoms ${ }^{3}$.

Advances in neuroimaging studies in aphasic stroke cases have enhanced the understanding of the effects of the

\footnotetext{
${ }^{1}$ Specialist in Language and Postgraduate Student of Health Science, School of Medical Sciences, Santa Casa de São Paulo, São Paulo SP, Brazil;

${ }^{2}$ Head of Discipline of Neurology, Department of Medicine, and Professor at the School of Medical Sciences, Santa Casa de São Paulo, São Paulo SP, Brazil; ${ }^{3} \mathrm{PhD}$ in Linguistics and Semiotics, Vice-Director of the Speech and Language Pathology School and Associate Professor at the School of Medical Sciences, Santa Casa de São Paulo, São Paulo SP, Brazil.

Correspondence: Michele Devido dos Santos; Discipline of Neurology, Department of Medicine, School of Medical Sciences, Santa Casa de São Paulo; Rua Cesário Mota Junior 61 / $8^{\circ}$ andar; 01221-020 São Paulo SP - Brasil; E-mail: m.devido@yahoo.com.br

Conflict of interest: There is no conflict of interest to declare.

Received 13 September 2011; Received in final form 14 November 2011; Accepted 21 November 2011
} 
lesion site, tasks, and treatment in this patient group. These insights might be expected to elucidate the structural relationships in neurologically healthy brain and enable greater accuracy of clinical diagnosis and better management. Clearer understanding and definition of damaged brain and subsequent neuronal degeneration can allow more effective assessment of different types of speech and language tasks ${ }^{5}$.

The aim of this study was to analyze aspects of language in relation to lesion topography in aphasics with a confirmed diagnosis of stroke.

\section{METHODS}

A prospective, descriptive study of quantitative and qualitative nature was conducted. The study sample comprised patients of both genders, aged over 15 years, and with basic level of schooling of at least three years, who had a confirmed diagnosis of ischemic stroke. All participants had previously undergone magnetic resonance imaging examinations, and their type of aphasia had been assigned based on the Hedge ${ }^{2}$ aphasia classification.

The patients included had suffered a stroke within the three-month period prior to the beginning of this study. The magnetic resonance imaging had been performed at the onset of symptoms.

Firstly, patients were selected randomly and the following were excluded: illiterate patients, dementia cases, and individuals with language impairments before the stroke. A total of 31 patients was enrolled in the study. The participants were divided into two groups: G1, aphasics (13 patients); and G2, non-aphasics (18 patients).

Language assessments were performed on the whole patient sample using three different language tests, namely: the Montreal Toulouse battery (alpha version) ${ }^{6}$, the Boston naming test ${ }^{7}$, and the verbal fluency test $(\mathrm{FAS})^{8,9}$. The Montreal Toulouse protocol is an excellent complete test for making a differential diagnosis of aphasia and it consists of the following tasks: guided interview; oral comprehension using words, simple and complex sentences; written comprehension using words, simple and complex sentences; copying of written sentences; word and sentence dictation; reading, repetition, and naming ${ }^{10}$. These specific tests were selected since this protocol had previously been validated for Brazilian Portuguese ${ }^{11-13}$.

A descriptive analysis was performed on the results because of the heterogeneity of the findings.

This study was previously approved by the Research Ethics Committee of the Hospital Irmandade da Santa Casa de São Paulo (project n. 254/08). All patients signed a free informed consent.

\section{RESULTS}

The 31 patients enrolled in this study were characterized by a balanced level of schooling: 12 patients (38.70\%) with elementary education; 10 (32.25\%) with high school education; and 9 (29.03\%) with university-level education. In G1, 22.58\% had had elementary schooling, $12.90 \%$ had reached high-school level, and $6.45 \%$ had reached university level. In G2, there was a balanced level of schooling: $16.12 \%$ with elementary schooling, $19.35 \%$ with high-school education, and $22.58 \%$ with universitylevel education.

Regarding age, 14 patients (45.16\%) were in the range from 15 to 39 years-old, $11(35.48 \%)$ were between 40 to 69 years-old and 6 (19.35\%) were over 70 years-old.

Because of the heterogeneity of the findings, a descriptive analysis was carried out to investigate the relationships between lesion, language test performance, and presence/absence of aphasia.

The performance results from the three language tests were compared against the topography of the lesions, aphasia type, and schooling level in G1, and they are shown in Table 1.

The performance of patients in the G1 Group was found to be compromised in several language assessment tests. The results regarding lesion topography were heterogeneous. They were highly heterogeneous with regard to correlations between aphasia type and lesion topography.

Table 2 shows the lesion topography and language test performance in G2. In contrast with G1 patients, G2 presented predominantly low verbal fluency in $47.36 \%$ of the cases and poorer performance in tasks of greater complexity in $15.78 \%$ of the cases. The results regarding lesion topography revealed heterogeneity.

\section{DISCUSSION}

Results revealed that the lesion sites were heterogeneous with regard to lesion topography and performance in language tasks between aphasics and non-aphasics and in relation to aphasia type and absence (Tables 1 and 2).

The present data indicated that there was no direct relationship between lesion topography, language task performance and stroke aphasia type.

Studies on subjects with subcortical lesions have described language compromise in this patient group. Radanovic et al. ${ }^{14}$ reported on a series of 14 patients with lesions exclusively in the subcortical regions (to basal ganglia and thalamus), of whom 10 were diagnosed with aphasia and presented compromised repetition, low verbal fluency, and impaired comprehension. Other studies by Benke et al. ${ }^{15}$ and Radanovic et al. ${ }^{16}$ described aphasic conditions 
Table 1. Lesion topography, aphasia type, schooling, and language test performance in G1.

\begin{tabular}{|c|c|c|c|}
\hline Lesion topography & $\begin{array}{l}\text { Aphasia } \\
\text { type }\end{array}$ & Schooling & $\begin{array}{l}\text { Language test performance } \\
\text { impaired tasks }\end{array}$ \\
\hline Left cerebellar peduncle & Wernicke & High & $\begin{array}{l}\text { Simple and complex oral and written sentence comprehension, } \\
\text { repetition, naming and verbal fluency for animals and phonemes/f/s/s/ }\end{array}$ \\
\hline $\begin{array}{l}\text { Left temporal lobe, left parietal lobe, } \\
\text { and right cerebellum hemisphere }\end{array}$ & Wernicke & Elementary & $\begin{array}{l}\text { Simple and complex oral and written sentence comprehension, } \\
\text { sentence repetition, and verbal fluency }\end{array}$ \\
\hline Right frontal lobe & Broca & Elementary & Naming, sentence repetition, and verbal fluency of phonemes /f/ /s/ \\
\hline $\begin{array}{l}\text { Left frontal lobe, left parietal } \\
\text { lobe and right occipital lobe }\end{array}$ & Broca & High & $\begin{array}{l}\text { Comprehension of complex written sentences, dictation, } \\
\text { reading, repetition, naming, and verbal fluency for animals and } \\
\text { phonemes/f//s/ }\end{array}$ \\
\hline $\begin{array}{l}\text { Internal capsule, left temporal lobe, } \\
\text { thalamus, lentiform nucleus }\end{array}$ & Global & Elementary & Compromised performance in all tests applied \\
\hline $\begin{array}{l}\text { Left frontal lobe, left temporal lobe, } \\
\text { left parietal lobe }\end{array}$ & Global & Elementary & Compromised performance in all tests applied \\
\hline Right cerebellar hemisphere & Global & Elementary & Compromised performance in all tests applied \\
\hline Left putamen & Global & Elementary & $\begin{array}{l}\text { Simple oral sentence comprehension, and complex written } \\
\text { sentences, sentence repetition, naming, and verbal fluency for } \\
\text { animals and } \\
\text { phonemes/f/s/ }\end{array}$ \\
\hline Left temporal lobe & Global & University & $\begin{array}{l}\text { Complex oral sentence comprehension, reading, repetition, naming, } \\
\text { and verbal fluency for animals and phonemes } / \mathrm{f} / \mathrm{s} / \mathrm{s}\end{array}$ \\
\hline $\begin{array}{l}\text { Left postcentral gyrus, and left and } \\
\text { right parietal lobes }\end{array}$ & Global & High & $\begin{array}{l}\text { Complex written sentence comprehension, repetition, naming, } \\
\text { and verbal fluency for animals and phonemes } / \mathrm{f} / \mathrm{s} /\end{array}$ \\
\hline Left temporal lobe & Global & Elementary & $\begin{array}{l}\text { Comprehension of complex sentence, comprehension of simple } \\
\text { and complex written sentence, reading, repetition, naming, } \\
\text { and verbal fluency for animals and phonemes /f/ /s/ }\end{array}$ \\
\hline $\begin{array}{l}\text { Left frontal lobe, left temporal lobe, } \\
\text { and left occipital lobe }\end{array}$ & Global & High & $\begin{array}{l}\text { Comprehension of complex sentence, comprehension of simple and } \\
\text { complex written sentence, reading, repetition, naming, and verbal } \\
\text { fluency of phonemes /f//s/ }\end{array}$ \\
\hline $\begin{array}{l}\text { Left frontal lobe and left } \\
\text { parietal lobe }\end{array}$ & Global & University & $\begin{array}{l}\text { Simple oral sentence comprehension, comprehension of words, } \\
\text { simple and written sentences, naming, and fluency for animals and } \\
\text { phonemes/f//s/ }\end{array}$ \\
\hline
\end{tabular}

s: phoneme s; f: phonemef.

Table 2. Lesion topography and language test performance in G2.

\begin{tabular}{|c|c|c|}
\hline Lesion topography & Schooling & Language test performance \\
\hline Right internal capsule & Elementary & Low on verbal fluency for phoneme/f/ \\
\hline Internal capsule and caudate nucleus & High & Low on verbal fluency for phoneme /s/ \\
\hline Right temporal lobe, right parietal lobe & Elementary & $\begin{array}{l}\text { Low on complex written sentence comprehension and } \\
\text { verbal fluency for phoneme /s/ }\end{array}$ \\
\hline Right internal capsule, left temporal lobe & University & Low on verbal fluency for phoneme /f/ \\
\hline Right parietal lobe & University & Low on verbal fluency for phoneme /f/ and /s/ \\
\hline $\begin{array}{l}\text { Left frontal lobe, left parietal lobe, left temporal } \\
\text { lobe, left cerebellum hemisphere, left putamen, } \\
\text { hippocampus, left lateral ventricle }\end{array}$ & Elementary & $\begin{array}{l}\text { Low on tasks of greater complexity: comprehension of } \\
\text { simple and complex written sentences, complex phrase repetition, } \\
\text { poor verbal fluency for phonemes /f/ and /s/ }\end{array}$ \\
\hline $\begin{array}{l}\text { Right frontal lobe, right parietal lobe, } \\
\text { right occipital lobe }\end{array}$ & High & $\begin{array}{l}\text { Significantly compromised verbal fluency for } \\
\text { phoneme/f/ and /s/ }\end{array}$ \\
\hline Periventricular matter & High & Low on verbal fluency for phoneme /f/ and /s/ \\
\hline Left perirolandic gyrus, cerebellar atrophy & Elementary & $\begin{array}{l}\text { Repetition of sentence of greater complexity and } \\
\text { compromised verbal fluency for phoneme /f/ }\end{array}$ \\
\hline $\begin{array}{l}\text { Periventricular white matter, right frontal gyrus, } \\
\text { bilateral basal ganglia }\end{array}$ & Elementary & Low on verbal fluency for phoneme /f/ and /s/ \\
\hline Left frontal gyrus, left insula & High & Normal \\
\hline Right bulb & High & Normal \\
\hline Right bulb & University & Normal \\
\hline Right temporal lobe & University & Normal \\
\hline Left parietal lobe & High & Normal \\
\hline Left parietal lobe & University & Normal \\
\hline Left transverse sinus, left sigmoid sinus & University & Normal \\
\hline $\begin{array}{l}\text { Right transverse sinus, right sigmoid sinus, left } \\
\text { bulb }\end{array}$ & University & Normal \\
\hline
\end{tabular}

s: phoneme s; f: phoneme f. 
secondary to lesions in the putamen, white matter, basal ganglia, and globus pallidus.

The results from the present study corroborate the findings from previous reports in the literature ${ }^{14-20}$. These reports described patients with lesions in a range of different regions, such as the putamen, cerebellum, thalamus, lentiform nucleus, internal capsule, cerebellar peduncle and the frontal, parietal and temporal areas of both hemispheres, which were associated with compromised language comprehension and expression.

Fabbro et al. ${ }^{17}$ and Ritcher et al. ${ }^{18}$ emphasized the importance of cerebellum involvement in aspects of cognition, including language impairments, such as low verbal fluency, difficulties in lexical access, and agrammatism. In a literature review to investigate the correlation between lesions and aphasia, Almeida et al. ${ }^{19}$ found no evidence to support such relationship. Similarly, Radanovic et al.16 and Mansur et al. ${ }^{20}$ corroborated this conclusion with heterogeneous results, which point towards absence of any relationship between lesion topography and aphasia.

Unexpectedly, language abnormalities were found in G2 patients, who manifested poor performance in verbal fluency tasks and difficulties on tests involving responses of greater complexity. This has led us to focus our attention on studying linguistic information processing, in a bid to associate this function with a specific region of the brain. Studies on brain organization have suggested explanations going from a theory of site-specific functions to theories favoring a functional view of the brain, in which it is integrated, flexible, and plastic ${ }^{21}$.

The influence of the phonological loop of semantic and linguistic processing on language comprehension tasks has been acknowledged. Phonological processing is associated with phrases in both the active and passive voices, while semantic and syntactic processing is involved in the construction of sentences and vocabulary. If the processes are incomplete, the functions become compromised ${ }^{22,23}$.

Studies on aphasics with lesions in the cortical, subcortical, and cerebellar regions have suggested that language processing takes place in the form of a neural circuit ${ }^{24-26}$.

Advances in functional neuroimaging techniques are making it possible to unveil the role of subcortical areas in language processing by enhancing the visualization of linguistic behavior and language processing. This line of research paves the way for future studies on the linguistic symbols semiology and for exploring the cerebral connections, which are required to maintain brain integrity ${ }^{27}$.

It is our belief that knowledge on correlates of lesion topography can contribute towards further investigations on the relationships between language processing, integrality of functions, and brain plasticity.

\section{References}

1. Diagnostic and statistical manual of mental disorders. $4^{a}$ ed. Washington, DC: American Psychiatric Association; 1994.

2. Hegde MN. Pocket guide to assessment in speech-language pathology. Toronto: Singular Thompson Learning; 2001

3. Mac-Kay APMG. Afasia. In: Mac-Kay APMG, Assencio-Ferreira VJ, Ferri-Ferreira TMS (Eds). Afasias e demências - avaliação e tratamento fonoaudiológico. São Paulo: Santos; 2003:47-59.

4. Bersano A, Burgio F, Gattinoni M, et al. Aphasia burden to hospitalized acute stroke patients: need for an early rehabilitation programme. Int J Stroke 2009;4:443-447.

5. Price CJ, Crinion J. The latest on functional imaging studies of aphasic stroke. Curr Opin Neurol 2005; 18:429-434.

6. Lecours AR, Mehler J, Parente MA, et al. Illiteracy and brain damage aphasia testing in culturally contrasted populations (control subjects). Neurops 1987; 25:231-245.

7. Kaplan EF, Goodglass H, Weintraub S. The Boston naming test. 2nd ed. Philadelphia: Lea \& Febiger; 1983.

8. Isaacs B, Kennie AT. The set test as an aid to the detection of dementia in old people. Br J Psychiatry 1973;123:467-470.

9. Bolla KI, Lindgren KN, Bonaccorsy C, et al. Predictors of verbal fluency (FAS) in the healthy elderly.J Clin Psychol 1990; 46:623-628.

10. Nespoulous JL, Lecours AR, Lafond D. MT-86 - Protocole MontréalToulouse d'examen linguistique de l'aphasie. Ortho-Edition: Isbergues; 1986.

11. Machado TH, Fichman HC, Santos EL, et al. Normative data for healthy elderly on the phonemic verbal fluency task - FAS. Dementia Neuropsych 2009;3:55-60
12. Brucki SM, Malheiros SM, Okamoto IH, Bertolucci PH. Normative data on the verbal fluency test in the animal category in our milieu. Arq Neuropsiquiatr 1997;5:56-61.

13. Mansur LL, Radanovic M, Araújo GC, Taquemori LY, Greco LL. Teste de nomeação de Boston: desempenho de uma população de São Paulo. Pro-Fono Rev Atual Cient 2006;18:13-20.

14. Radanovic M, Mansur LL, Azambuja MJ, Porto CS, Scaff M. Contribution to the evaluation of language disturbances in subcortical lesions: a pilot study. Arq Neuropsiquiatr 2004;62:51-57.

15. Benke T, Delazer M, Bartha L, Auer A. Basal ganglia lesions and the theory of fronto-subcortical loops: neuropsychological findings in two patients with left caudate lesions. Neurocase 2003;9:70-85.

16. Radanovic M, Azambuja M, Mansur LL, Porto CS, Scaff M. Thalamus and language: interface with attention, memory and executive functions. Arq Neuropsiquiatr 2003;61:34-42.

17. Fabbro F, Moretti R, Brava A. language impairments in patients with cerebellar lesions. J. Neurolinguistics 2000;13:173-188.

18. Richter S, Gerwig M, Aslan B, et al. Cognitive functions in patients with MR-defined chronic focal cerebellar lesions. J Neurol 2007; 54:1193-1203.

19. Almeida LMS, Ortiz KZ, Oura M,Onoda RM,Araujo AA. Afasia:correlações entre as manifestações descritas e o diagnóstico de neuroimagem. Fono Atual 2007;6:32-38.

20. Mansur LL, Radanovic M, Rüegg D, Mendonça LIZ, Scaff M. Descriptive study of 192 adults with speech and language disturbances. Sao Paulo Med J/Rev Paul Med 2002;120:170-174.

21. Kang EK, Sohn HM, Han MK, et al. Severity of post-stroke aphasia 
according to aphasia type and lesion location in Koreans.J Korean Med Sci 2010;25:123-127.

22. Berndt RS, Mitchum CC, Wayland S. Patterns of sentence comprehension in aphasia: a consideration of three hypotheses. Brain Lang 1997;60:197-221.

23. Caramazza A, Basili AG, Koller J, Berndt RS. An investigation of repetition and language processing in a case of conduction aphasia. Brain Lang 1981;14:235-271.

24. Madalozzo D. As correlações clínico-topográficas das afasias. [tese]. São José do Rio Preto: Faculdade de Medicina do São José Rio Preto; 2007.
25. Connor LT, DeShazo Braby T, Snyder AZ, Lewis C, Blasi V, Corbetta M. Cerebellar activity switches hemispheres with cerebral recovery in aphasia. Neuropsychologia 2006;44:171-177.

26. Stoodley CJ, Schmahmann JD. The cerebellum and language: evidence from patients with cerebellar degeneration. Brain Lang 2009;110: 149-153.

27. Small SL, Nusbaum HC. On the neurobiological investigation of language understanding in context. Brain Lang 2004;89:300-311. 